\title{
The sphenacodontid synapsid Neosaurus cynodus, and related material, from the Permo-Carboniferous of France
}

\author{
Jocelyn Falconnet \\ Acta Palaeontologica Polonica 60 (1), 2015: 169-182 doi: http://dx.doi.org/10.4202/app.2012.0105
}

Sphenacodontid synapsids were major components of early Permian ecosystems. Despite their abundance in the North American part of Pangaea, they are much rarer in Europe. Among the few described European taxa is Neosaurus cynodus, from the La Serre Horst, Eastern France. This species is represented by a single specimen, and its validity has been questioned. A detailed revision of its anatomy shows that sphenacodontids were also present in the Lodève Basin, Southern France. The presence of several synapomorphies of sphenacodontids-including the teardrop-shaped teeth-supports the assignment of the French material to the Sphenacodontidae, but it is too fragmentary for more precise identification. The discovery of sphenacodontids in the Viala Formation of the Lodève Basin provides additional information about their ecological preferences and environment, supporting the supposed semi-arid climate and floodplain setting of this formation. The Viala vertebrate assemblage includes aquatic branchiosaurs and xenacanthids, amphibious eryopoids, and terrestrial diadectids and sphenacodontids. This composition is very close to that of the contemporaneous assemblages of Texas and Oklahoma, once thought to be typical of North American lowland deposits, and thus supports the biogeographic affinities of North American and European continental early Permian ecosystems.

Key words: Synapsida, Sphenacodontidae, anatomy, taxonomy, ecology, Carboniferous, Permian, France.

Jocelyn Falconnet [falconnet@mnhn.fr], CR2P UMR 7207, MNHN, UPMC, CNRS, Département Histoire de la Terre, Muséum national d'Histoire naturelle, CP 38, 57 rue Cuvier, F-75231 Paris Cedex 05, France.

This is an open-access article distributed under the terms of the Creative Commons Attribution License (for details please see creativecommons.org), which permits unrestricted use, distribution, and reproduction in any medium, provided the original author and source are credited. 
For 5 Full text (598.6 kB) 